NBER WORKING PAPER SERIES

\title{
BRIBERY: WHO PAYS, WHO REFUSES, WHAT ARE THE PAYOFFS?
}

\author{
Jennifer Hunt \\ Sonia Laszlo \\ Working Paper 11635 \\ http://www.nber.org/papers/w11635
}

\author{
NATIONAL BUREAU OF ECONOMIC RESEARCH \\ 1050 Massachusetts Avenue \\ Cambridge, MA 02138 \\ September 2005
}

We are grateful to Vincent Chandler for excellent research assistance and to the Instituto Nacional de Estadística e Información for the data. We thank Miriam Golden, Yossi Greenberg, Franque Grimard, Miguel Jaramillo Baanante, Daniel Parent, Jan Svejnar, Kathy Terrell, Duncan Thomas and seminar participants at GRADE, Lausanne, Laval, Maryland, McGill, Michigan, UQAM, and CEPR/BREAD for comments. Hunt is also affiliated with the CEPR, IZA and DIW-Berlin, and acknowledges the Social Science and Humanities Research Council of Canada for financial support. Laszlo is also affiliated with Grupo de Análisis para el Desarrollo (GRADE) in Lima. The views expressed herein are those of the author(s) and do not necessarily reflect the views of the National Bureau of Economic Research.

(O2005 by Jennifer Hunt and Sonia Laszlo. All rights reserved. Short sections of text, not to exceed two paragraphs, may be quoted without explicit permission provided that full credit, including $\odot$ notice, is given to the source. 
Bribery: Who Pays, Who Refuses, What Are the Payoffs?

Jennifer Hunt and Sonia Laszlo

NBER Working Paper No. 11635

September 2005

JEL No. H4, K4, O1

\title{
$\underline{\text { ABSTRACT }}$
}

We provide a theoretical framework for understanding when an official angles for a bribe, when a client pays, and the payoffs to the client's decision. We test this framework using a new data set on bribery of Peruvian public officials by households. The theory predicts that bribery is more attractive to both parties when the client is richer, and we find empirically that both bribery incidence and value are increasing in household income. However, $65 \%$ of the relation between bribery incidence and income is explained by greater use of officials by high-income households, and by their use of more corrupt types of official. Compared to a client dealing with an honest official, a client who pays a bribe has a similar probability of concluding her business, while a client who refuses to bribe has a probability 16 percentage points lower. This indicates that service improvements in response to a bribe merely offset service reductions associated with angling for a bribe, and that clients refusing to bribe are punished. We use these and other results to argue that bribery is not a regressive tax.

\author{
Jennifer Hunt \\ Department of Economics \\ McGill University \\ Leacock Building, Room 443 \\ 855 Sherbrooke Street West \\ Montréal H3A 2T7 \\ CANADA \\ and NBER \\ jennifer.hunt@mcgill.ca
}




\section{Introduction}

It is now widely accepted that corruption has negative economic consequences. RoseAckerman's influential early work warned that the assumptions required for corruption to enhance efficiency were unlikely to be satisfied in practice. ${ }^{1}$ More recent theoretical contributions on the causes and consequences of corruption have also emphasized efficiency losses. Shleifer and Vishny (1993) suggest that bribery of public officials has economic effects that can prove more distortionary than taxation. ${ }^{2}$ Empirical work has substantiated these fears: Mauro (1995) finds cross-country evidence that corruption reduces economic growth. Moreover, many development economists fear that corruption reduces equity as well as efficiency, constituting a regressive tax, causing the poor to be excluded from public services, and skewing growth in favor of the rich. ${ }^{3}$

Until recently, however, micro-level data measuring corruption, essential for understanding underlying mechanisms and distributional consequences, were lacking. Most empirical research on the causes and consequences of corruption is not only conducted at the macro (country) level, it is almost exclusively based on perceptions of corruption, rather than actual, measured corruption. ${ }^{4}$ We exploit newly available data from Peru to characterize bribery-related interactions between public officials and households, and to measure the burden of bribery across income classes. Our paper is one of a small but growing number using micro data on bribery. Of these, Svensson (2003), who finds that more profitable firms pay larger bribes, and Kaufmann and Wei (1999), who find that firms commonly paying bribes spend more time on red tape, are the only others to test micro predictions of theoretical models of the bribery process. ${ }^{5}$

\footnotetext{
${ }^{1}$ Rose-Ackerman $(1975,1978)$. Lui $(1985)$ highlights the beneficial side of bribery.

${ }^{2}$ See also Choi and Thum (2004), Kingston (2004), Sah (1988) and Aidt's (2003) survey.

${ }^{3}$ E.g. Gupta, Davoodi and Alonso-Terme (1998) and Kaufmann et al. (1998).

${ }^{4}$ E.g. Fisman and Gatti (2002), Mauro (1995), Treisman (2000). Olson et al. (2000) critique this type of data.

${ }^{5}$ Deininger and Mpuga (2004), Hunt (2004), Hunt (forthcoming), Mocan (2004) and Swamy et al. (2001) use data on individual bribery. Di Tella and Schargrodsky (2003) can convincingly infer corruption at the hospital level.
} 
Our survey measures actual bribery, and is representative of the entire population of a country, thus principally capturing bribes paid in the course of daily life. Such "petty" bribes represent the most common form of corruption. These are the bribes that affect the poor most directly, and that might constitute a regressive tax. Furthermore, petty bribery of low-level public officials can cause corruption to spread upwards through the hierarchy of officials. ${ }^{6}$ Contagion may also occur if people who pay bribes routinely as individuals are more willing to bribe or accept bribes in their capacity as firm representative or political actor. In most countries, respondents to Transparency International's Global Corruption Barometer judged "petty or administrative" corruption to be almost as serious a problem as "grand or political corruption." 7

Concerns about petty corruption in Peru, a middle-ranking country in Transparency International's Corruption Perceptions $\operatorname{Index}^{8}$, led the Peruvian statistical agency to include a module on bribery in the 2002 and 2003 national household surveys. We take advantage of the information about respondents' use of public officials, whether they bribed or refused to bribe, how much they paid if they bribed, as well as the quality of the services that they received from the official.

We first build a theoretical framework allowing us to understand the bribery-related interactions between public officials and clients. Under what circumstances do officials angle for a bribe? Which clients pay and how much? What does bribery buy in terms of service? In our model, officials angle for a bribe by shirking, and punish with further shirking clients who refuse to bribe. Since richer clients have a higher valuation of time, they are more willing to bribe and, conditional on bribing, pay a higher bribe. Thus, officials are more likely to angle for a bribe from a rich client. If a client chooses to pay a bribe, the official rewards her with a reduction in red tape that will at least partially offset the earlier shirking.

We then evaluate the model with the data. The results suggest that it is indeed

\footnotetext{
${ }^{6}$ Cadot (1987).

${ }^{7}$ Transparency International (2004b).

${ }^{8}$ Transparency International (2004a).
} 
most commonly the official who moves first in the process leading to bribery, and that he does take client income into account in his decisions. We find that bribery incidence is strongly increasing in client income. Our results suggest, however, that at least $65 \%$ of this relationship is driven by the fact that the non-poor use more officials than the poor, and use a more corrupt mix of officials. Therefore, at most $35 \%$ of the higher bribery of the non-poor is owing to a higher probability of bribery conditional on using a particular official type. Doubling a client's income increases this probability by 0.2 percentage points. We find an income-elasticity of the bribe amount of about 0.3. Our results suggest that officials practice first-degree price discrimination rather than thirddegree price discrimination, but are not conclusive on this point.

Compared with a client dealing with an official acting honestly, a client who pays a bribe reluctantly has a slightly lower probability of concluding her business with the official, a client who pays a bribe voluntarily has a similar probability, while a client who refuses to bribe has a much lower probability (by 16 percentage points). This points to an offsetting effect between service improvements facilitated by the payment of the bribe and the service reduction associated with the angling for a bribe, and to the punishment of clients refusing to bribe.

Our data show that among users of officials, bribery is not a regressive tax, but is at worst a flat tax. Although we cannot directly examine whether corruption disproportionately discourages the poor from using officials, the results suggest that any such effect is small. The main distributional consequence of bribery appears to be a transfer from clients to officials, in return for no net improvement in service.

\section{Corruption in Peru}

The enormous scale of grand corruption in Peru was revealed in 2000 by discoveries leading to the resignation and self-exile of the president, Alberto Fujimori. Video-taped evidence showed that Vladimir Montesinos, Fujimori's spy chief, had repeatedly bribed congressmen to defect to Fujimori's party to ensure its majority in congress. In addition, 
large bribes had enabled Montesinos to control most of the media and influence the judiciary. $^{9}$

However, Fujimori is credited with having reduced petty corruption. His administration pursued policies reducing the role of government, which he justified not only on efficiency grounds, but on the grounds that reducing the role of government would reduce opportunities for corruption. He attempted to reduce corruption in the police and municipal governments, in the latter case by establishing a supervisory agency to field citizen complaints. However, his reforms of the judiciary are thought to have made it more corrupt.

Despite some progress, however, several institutions with which ordinary people have much contact were judged to be corrupt by Transparency International in a November 2001 report. ${ }^{10}$ An increase in the number of temporary judges, appointed in part to help clear backlogs, had contributed to corruption. Such judges, representing 74 per cent of all judges, were vulnerable to political pressure and susceptible to corruption because of their lack of job security.

The morale of the police was thought to be lowered by poor pay and equipment, which combined with weak internal controls and sanctions rendered them susceptible to small and large-scale corruption, as well as to cooperation with criminals. At this time it was customary to bribe the transit police. ${ }^{11}$

Public administration generally was corrupted by poor pay, complex procedures for sanctioning bribe-taking, and the frequent overturning of administrative sanctions by the judiciary. Only public servants whose contracts had been converted to private sector terms were well-paid, but they lacked the job security that would protect them from political interference (and, presumably, allow them to report corruption by superiors).

The interim and Alejandro Toledo administrations that followed Fujimori made corruption a priority, but focused particularly on prosecuting actors in the Montesinos affair.

\footnotetext{
${ }^{9}$ See McMillan and Zoido (2004).

${ }^{10}$ Most of this section is based on this report: Transparency International (2001a). See also Transparency International (2001b) and World Bank (2001a, 2001b).

${ }^{11}$ Anecdotal evidence suggests that making the Lima transit police all-female reduced bribery.
} 
Nevertheless, a set of anti-corruption proposals was drawn up in 2001 by a group including representatives of civil society and the World Bank. Some initiatives put into place include the naming of an "Anti-Corruption Tsar", the establishment of a special anti-corruption police division, and the introduction of an anti-nepotism law for the public service. Ominously, however, the Tsar was fired in December 2004 after seeking to investigate accusations of corruption in the Toledo administration. ${ }^{12}$

\section{Theoretical Model}

In our theoretical model, two agents, the public official and the client, interact in a twostage game. The official has a monopoly on the service he provides. The official plays first, and decides whether to angle for a bribe or not. If the official does not angle for a bribe, he carries out his job 'honestly' in both stages (which means not shirking, and following required procedures, including possibly unnecessary red tape). If he angles for a bribe, he shirks in the first stage, which either conveys to the client that she should bribe, or sets the stage for the official actually asking for a bribe. There is no distinction between these two possibilities in the model, but we assume that either way the official can set the amount of the bribe. The client then bribes, or does not bribe. If she does not bribe, the official punishes her by shirking in the second stage as well. ${ }^{13}$

For bribery to be attractive to both official and client, it must yield something beneficial to both. For the official the benefit is obviously the bribe. We assume that in return for the bribe, the official can offer a service to the client that is effortless to the official: putting the client's case at the front of the queue, or waving certain paperwork (red tape). This is a service on top of the service provided by an official behaving 'honestly' who requires compliance with all red tape. ${ }^{14}$

\footnotetext{
${ }^{12}$ www.signonsandiego.com/news/world/20041217-0702-peru-corruption.html

${ }^{13}$ The client in Cadot (1987) is also punished if she refuses to bribe, but may attempt to denounce the official and have him fired. She then attempts to conduct her business with his replacement.

${ }^{14}$ The official's control over red tape at low cost is reminiscent of Banerjee (1997). In his model, the official manipulates red tape to induce the client to reveal her valuation of the service, whereas in our model red tape reduction is merely an inducement for the client to bribe. In Kaufmann and Wei (1999)
} 
The amount or value of the time or effort saved by bribing can be viewed as dependent on the organizational structure of the official's particular bureaucracy, or can be viewed as a function of client income: the richer the client, the more valuable her time, and the more valuable a given reduction in bureaucracy. Rose-Ackerman (1978, chapter 6) discusses whether it is more plausible that officials practice first-degree pricediscrimination, by charging each client a different price, or whether they practice thirddegree price-discrimination, by offering different levels of red-tape reduction for different bribe amounts. We do not model the latter, but consider it in the empirical section. ${ }^{15}$

\subsection{Model}

If the official is honest in both stages, he experiences disutility of effort $E$ per stage, and utility $U_{O}$ per stage from having discharged his duty with appropriate effort, according to the rules and without taking bribes. His wage is normalized to zero. The total utility of the honest official is therefore

$$
2\left(U_{O}-E\right)
$$

When considering whether to angle for a bribe or not, the official must consider whether he can induce the client to bribe in the second stage, so we first examine the bribery versus punishment alternatives that follow from the official angling for a bribe. If the client does bribe, the official exerts effort $E$ in the second stage and receives bribe $B$. The official's second stage utility is therefore:

$$
B-E .
$$

If the client refuses to bribe, the official shirks in the second stage, exerting no effort, and has a utility of zero. Therefore, the official prefers receiving a bribe to punishing the client by shirking if the bribe gives more utility than the disutility of effort:

$$
B>E \text {. }
$$

the official increases the amount of red tape to induce the client to bribe to reduce it.

${ }^{15}$ Price-discrimination is not inconsistent with the claim often made that for particular transactions 'everyone knows how much you have to bribe'. People in rich circles may know the price for rich people, and be unaware that people in poor circles 'know' a lower price. 
To induce the client to bribe, however, the official must make an offer that is attractive to the client. If she bribes, the client receives utility $E$ from the effort the official is exerting, and receives utility $R$ from having reduced bureaucracy. If she refuses to bribe, she will simply get utility $U_{C}$ from having refused to bribe, and no utility from services from the official who is exerting no effort. $R, U_{C}$ and $U_{O}$ are independent. The client therefore chooses to bribe if $E+R-B>U_{C}$, which implies

$$
B<E+R-U_{C}
$$

From (3) and (4), if both official and client prefer bribery, it must be that $R>U_{C}$ : the benefit to the client from reduced bureaucracy must be greater than the utility she gets from refusing to bribe. This may be because the service provided by that official is particularly bureaucratic, because the client is rich and thus values time highly, or because the client has few scruples.

\subsection{The official can observe the client's scruples}

Initially we assume that the official can observe the client's $U_{C}$ : below we relax this. The official cannot affect the utility he or the client gets from punishment, but he can maximize the utility he gets from bribery (2) by picking the largest bribe $B$ subject to the constraint that the client will choose to bribe (4). This means the official will choose ${ }^{16}$

$$
B^{*}=E+R-U_{C}
$$

The official can get a higher bribe if he has something more valuable to offer in time savings $(R)$, if the client is unscrupulous (low $U_{C}$ ) or if normal effort $E$ is high (the client has a lot to lose from punishment). The official's utility in the second stage if the client bribes is therefore given by substituting (5) into (2):

$$
R-U_{C}
$$

The expression does not depend upon normal effort $E$, because the bribe will compensate for this. The official therefore decides whether or not to angle for a bribe by

\footnotetext{
${ }^{16}$ We assume that when the client is indifferent she chooses to bribe.
} 
comparing the total utility of honest behavior (1) with the sum of second stage utility from bribery (6) and zero utility from shirking in the first stage. He chooses honesty if $2\left(U_{O}-E\right)>R-U_{C}$, which implies

$$
U_{O}>E+\frac{R-U_{C}}{2}
$$

The official chooses honesty if he has high scruples (high $U_{O}$ ), and chooses to angle for a bribe if he can offer the client something valuable compared to the client's scruples (high $R-U_{C}$ ), and if the normal effort $E$ of being honest is high (bribery is appealing because no effort is exerted in the first period). It is irrelevant whether the client prefers honesty or angling for a bribe, since the official's monopoly position allows him to choose.

If $R<U_{C}$ either the official or the client will not accept bribery, and the official will choose between honest behavior (1) and shirking in both stages (zero utility). He will choose honesty if the utility from honesty is greater than the effort of work:

$$
U_{O}>E
$$

The model does not explicitly incorporate a danger that the official will be caught either shirking or bribing. However, the structure of the model is the same as that of the following model. The official has no scruples $\left(U_{O}=0\right)$, but with probability $\delta$, the official risks being caught if he shirks or takes a bribe. If he is caught, his wages are docked by $F$, or he must pay a bribe of $F$ to his superior to avoid being fired. ${ }^{17}$ By choosing to angle for a bribe, he therefore has an expected loss of $2 \delta F$ from being caught. The solution to this model is given by equations (7) and (8) with $U_{O}$ replaced by $\delta F$, and the interpretation is that the official is less likely to angle for a bribe if the probability of detection $\delta$ is high, or the punishment $F$ is high. ${ }^{18}$

\footnotetext{
${ }^{17}$ Andvig and Moene (1989), Cadot (1987) and Rose-Ackerman (1978, chapter 9) model interactions with corrupt superiors. See also Prendergast (2001).

${ }^{18}$ Mookherjee and Png (1995) present a model that overturns this simple intuition.
} 


\subsection{The official cannot observe the client's scruples}

It is plausible that the official knows $R$. If $R$ is principally a parameter describing the official's bureaucracy he will know it, and if $R$ represents the client's ability to pay, the official can judge this at least to some extent from the client's appearance and address. It is less plausible that an official can evaluate the client's aversion to dishonesty $\left(U_{C}\right)$. We assume, however, that the official knows the distribution of $U_{C}$, and chooses $B^{*}$ with this knowledge. Some clients will now choose not to bribe if the official angles for a bribe. ${ }^{19}$

Under these circumstances, a risk-neutral official who angles for a bribe picks the bribe to maximize the expected payoffs. ${ }^{20}$ The payoff from punishing the client is zero for the official, so the official's problem reduces to maximizing the probability of the client agreeing to bribe $(\gamma)$ times its payoff, with the latter given by (2).

Assume that $U_{C}$ is uniformly distributed along the interval $\left[\underline{U}_{C}, \bar{U}_{C}\right]$. If the official asks for a bribe, (4) implies the client will pay it if

$$
U_{C}<E+R-B
$$

The probability $\gamma$ that the client pays is therefore

$$
\gamma=P\left(U_{C}<E+R-B\right)=\frac{E+R-B-\underline{U}_{C}}{\bar{U}_{C}-\underline{U}_{C}} .
$$

The official therefore picks $B$ to maximize $\gamma(B-E)$ :

$$
\max _{B} \frac{E+R-B-\underline{U}_{C}}{\bar{U}_{C}-\underline{U}_{C}}(B-E) .
$$

From the first order condition,

$$
B^{*}=E+\frac{R-\underline{U}_{C}}{2} .
$$

The bribe maximizing the expected utility from angling for a bribe with heterogeneous clients with unobservable scruples is increasing in the effort $E$ required to do the official's

\footnotetext{
${ }^{19}$ In a different model the client could signal her willingness to bribe. Our modelling of the official moving first is inspired by the empirical results.

${ }^{20}$ Cadot (1987) examines closely the implications of the official's being risk averse.
} 
job honestly (punishment is costly to the client), and increasing in the surplus available for the least scrupulous client $\left(R-\underline{U}_{C}\right)$.

From (12) and (10), the probability of the client bribing is

$$
\gamma=\frac{1}{2} \frac{\left(R-\underline{U}_{C}\right)}{\left(\bar{U}_{C}-\underline{U}_{C}\right)}
$$

while from (12) the payoff $B-E$ is

$$
\frac{1}{2}\left(R-\underline{U}_{C}\right)
$$

The expected payoff $\gamma(B-E)$ from angling for a bribe is the product of the two:

$$
\frac{1}{4} \frac{\left(R-\underline{U}_{C}\right)^{2}}{\left(\bar{U}_{C}-\underline{U}_{C}\right)}
$$

and the official chooses honest behavior over angling for a bribe if (1) is greater than (15), and therefore:

$$
U_{O}>E+\frac{1}{8} \frac{\left(R-\underline{U}_{C}\right)^{2}}{\bar{U}_{C}-\underline{U}_{C}} .
$$

The official is likely to choose honest behavior over angling for a bribe if he has high scruples $\left(U_{O}\right)$, and is likely to angle for a bribe if normal effort $E$ is high (he need not exert any effort in the first period), if there is a narrow range of scruples among clients (the less desirable punishment outcome can more frequently be avoided), and if the surplus available for the least scrupulous client is high.

If $R<\underline{U}_{C}$, either the official or the client will not want bribery (which means the corner solution of $\gamma=0$ will not arise). In this case the official's choice is between honest behavior and punishment. The official will prefer honest behavior if $U_{O}>E$, as in the case when the client's scruples are observable.

If $R>2 \bar{U}_{C}-\underline{U}_{C}$, the official would like to set a bribe that induces $\gamma>1$ of the clients to bribe. Since this is impossible, he chooses a corner solution, where he picks the bribe that just persuades all clients to bribe $(\gamma=1)$, using $(10)$ :

$$
B^{*}=E+R-\bar{U}_{C} .
$$

At this corner solution the official's (positive) utility is $R-\bar{U}_{C}$, and he chooses honesty over angling for a bribe if $2\left(U_{O}-E\right)>R-\bar{U}_{C}$, and hence $U_{O}>E+\frac{1}{2}\left(R-\bar{U}_{C}\right)$. 
The model can easily be extended to the case where the disutility to the official of providing normal effort $\left(E_{O}\right)$ is not equal to the utility his normal effort provides to the client $\left(E_{C}\right)$. This allows for the possibility that richer clients value normal service more than poorer clients. The only qualitative difference with this extension is that if $E_{C}$ is high enough relative to $E_{O}$, the official can extract a bribe in return for only normal service in the second stage, providing no reduction in bureaucracy $(R=0)$.

\subsection{Empirical implications}

Although we cannot observe a client's utility, we have measures in the data of the quality of the service she receives. The model predicts that the clients receiving the worst service are those who refuse to bribe when a bribe is angled for: they receive zero service. Clients receiving honest service receive $2 E$ in services from the official, while those paying a bribe receive $E+R$. If we view $R$ as an organizational parameter, the difference in service between these two groups is $E-\bar{R}$, where $\bar{R}$ is the average $\mathrm{R}$ computed over officials who successfully angle for a bribe (and therefore higher than when computed across all officials). In the model $R$ and $E$ are independent, so the gap cannot be signed, but the empirical work can give the relevant magnitudes for the official-client pairs where a bribe is exchanged. If $E-\bar{R}$ is positive, clients dealing with an official acting honestly are better off in equilibrium, since the effort he provides in the first stage more than offsets the bureaucracy reduction his acting dishonestly provides in the second stage.

The model predicts the relation between income and bribery, if we instead interpret the utility $R$ as stemming from a valuation of reduced bureaucracy. The rich have higher $R$, so are more willing to bribe and to pay a higher bribe conditional on bribing, for given scruples. The official is therefore more likely to angle for a bribe from a rich than a

poor client. It is ambiguous whether the probability of refusing a bribe compared to the probability of the official acting honestly is larger for the rich or the poor: the rich are less likely to face an official acting honestly, but are less likely to refuse to pay a bribe if one is angled for. 


\section{Data}

\subsection{The survey}

We use data from a large, nationally and regionally representative, household survey from Peru. The Encuesta Nacional de Hogares (ENAHO), conducted yearly by Peru's national statistical agency Instituto Nacional de Estadística e Información (INEI), contains detailed information about individual and household characteristics. Rural regions are over-sampled. Over 18,000 households responded to each of the 2002 and 2003 surveys. Of particular importance to our study, in 2002 and 2003 the ENAHO included a detailed module on governance, democracy and transparency that gathers information about the use of public officials. One respondent per household (half are the household head) is asked numerous questions pertaining to the household's use of 21 different types of officials. If a particular type of official was used in the last twelve months, then respondents are asked a series of questions in connection with use of this official type in this time-frame, and possible bribery: whether the official asked for a bribe, gift, tip or "coima" (slang for bribe), whether the respondent felt obliged to bribe, bribed voluntarily, or refused to bribe, and the amount of the bribe if she bribed.

The module also asks respondents about the quality of the services received from the official type: whether they saw an official immediately, the number of visits to the official, whether they concluded their business with the official, whether they consider the services received to be "good", "regular" or "bad" and whether they wasted significant time or money in connection with using the official (for example, on transportation). It is not possible to know for how many different purposes the client used the official. The question about the amount paid specifies that the value of in-kind payments should be included, but is ambiguous about whether the amount should be the sum or the average of bribes paid to the official type. ${ }^{21}$

\footnotetext{
21 "On average, what was the total...?"
} 


\subsection{Descriptive statistics}

Columns 1 and 2 of Table 1 show $4.9 \%$ of households, and $5.7 \%$ of households using at least one official, reported having bribed (or tipped etc.) or refused to bribe in the previous twelve months (a bribery "episode"). As we discuss in detail in the Data Appendix, although this is likely to be an underestimate of the true bribery episode rate, we do not believe the underestimation to be severe. Table 1 column 3 shows that among households that had experienced at least one bribery episode, the average number of episodes was only 1.2. Most households ( $87 \%$ in column 1) had used at least one type of official, and the average number used was 2.5. Household quarterly consumption is greater in the sample of respondents who reported a bribery episode: 5025 Nuevos Soles compared to 3656 Nuevos Soles for all households (one Nuevo Sol is about 30 U.S. cents). The share of extremely poor households is correspondingly lower in the bribery episode sample. The magnitude of the bribes relative to quarterly consumption is relatively low, at $2 \%$ in column 4. Appendix Tables 1 and 2 provide means of other respondent and household characteristics.

Table 2 provides the characteristics of bribery episodes using household-official pairs as the unit of observation (the unit of observation for the rest of the paper). For pairs where a bribery episode occurred, in $48 \%$ of cases the official solicited the bribe, in $22 \%$ of cases the respondent felt obliged to bribe, and in only $8 \%$ of cases did the respondent voluntarily bribe (column 3). The respondent refused to bribe in $22 \%$ of cases.

The average number of visits to officials is about five for all users and for the bribery episode samples, but this average conceals an unusual distribution: as shown in column 2, $21 \%$ of users visit the official twelve times. Clients with twelve visits are concentrated among the water, gas and electric utilities, and to a lesser extent the state banks. These are presumably monthly users transacting more routine business than other clients, such as paying bills. This interpretation is supported by the fact that among clients with a bribery episode, only $3 \%$ had twelve visits. We therefore view visiting twelve times as a proxy for the monthly use of simple services. 
Although $93 \%$ of clients concluded their business, the share is only $74 \%$ for those with a bribery episode. This pattern is replicated qualitatively with the other measures of service: whether it was judged to be good or bad by the client and whether the client saw the official immediately. Service is always worse for the bribery episode sample. Given the phrasing and position of the question on concluding business, a positive response does not appear to imply necessarily that the business was concluded successfully. We view this variable as a proxy for the speed of service, whatever the outcome.

Certain officials have a disproportionate share of bribery episodes relative to the share of households using the official. Table 3 lists official types, with some types combined, in order of their share of bribery episodes. (The Data Appendix gives the full list of official types.) The police account for $35 \%$ of bribery episodes (column 2) and the city (municipal) government for $21 \%$, with the judiciary in third rank with $12 \%$. These three institutions account for $68 \%$ of bribery episodes. Column 3 shows that these institutions are even more dominant in terms of total bribe payments: the judiciary alone accounts for $42 \%$ of the money paid in bribes, followed by the police with $27 \%$ and city government with $11 \%$, making a total of $80 \%$. As the judiciary and police are only used by $4 \%$ and $6 \%$ of households respectively (column 4), it is clear that these institutions are extremely corrupt.

\section{Empirical Specification}

Our empirical tests fall into two categories: tests of who pays bribes, and tests of the payoffs for the parties involved. The unit of observation is the household-official pair. For the first category we run regressions on different samples with the following specification:

$$
Y_{i j t}=\mu_{j}+\gamma_{t}+\beta_{1} W_{i t}+\mathbf{X}_{\mathbf{i t}} \beta_{2}^{\prime}+\beta_{3} Z_{i j t}+\epsilon_{i j t}
$$

where $j$ indexes the official type, $i$ the household and $t$ the survey year, and $Y_{i j t}$ is the outcome variable of interest: probability of a bribery episode (either for the full sample, or for the sample of observations where the official is used), probability of using an official 
(full sample), or number of visits to the official (sample where the official is used). $\mu_{j}$ are official-type fixed effects, $\gamma_{t}$ is a dummy for the 2003 survey, $W_{i t}$ is a measure of $(\log )$ household income or consumption, or a poverty indicator, and $X_{i t}$ contains the other characteristics of the respondent and household. The only covariate $\mathrm{Z}$ varying by $i$ and $j$ is a dummy for whether a household visited a particular official type twelve times. According to the dependent variable, (18) is estimated using probits or ordinary least squares.

When we are interested in the payoff to bribery, for the official or the client, we estimate equations of the following form:

$$
H_{i j t}=\mu_{j}+\gamma_{t}+\beta_{1} W_{i t}+\mathbf{X}_{\mathbf{i t}} \beta_{2}^{\prime}+\beta_{3} Z_{i j t}+\mathbf{B X}_{\mathbf{i j t}} \beta_{4}^{\prime}+\epsilon_{i j t}
$$

The notation and specification here are the same as in (18), except that $B X_{i j t}$ are dummies for whether the respondent had one of the possible bribery episodes (bribed voluntarily, felt obliged to bribe, was asked by the official to bribe, and was asked but refused to bribe), and the outcomes $H_{i j t}$ are the (log) amount of bribe paid (for the sample who paid bribes), whether the client successfully concluded her business with the official, the client's subjective rating of the service quality, and whether the client saw the official immediately (all for the sample where the official is used). According to the dependent variable, (19) is estimated using probits or ordinary least squares. The theoretical model makes clear that $B X_{i j t}$ is endogenous: in the absence of convincing instruments, we use the theoretical model to interpret the results.

Household consumption is our preferred measure of $W_{i t}$, or what we call "income" in the model, as it may be considered a measure of permanent income. It is arguably a client's permanent income that an official will best be able to assess, based on information such as address, dress, and vehicle ownership. We report the marginal effects or coefficients on the value of consumption and the consumption-based poverty indicators provided in the data set. Results using expenditure instead of the value of consumption are very similar. However, the effects of the various income measures (net/gross, total/monetary) are smaller, in some cases as low as one-third the size of the consumption effect. 
We are concerned that measurement error may bias the consumption coefficients towards zero, so in addition to running the specifications reported below, we have run all regressions instrumenting consumption with net total income. ${ }^{22}$ However, this did not in general raise the point estimates, suggesting that measurement error is non-classical or correlated between consumption and income. In all regressions we cluster standard errors at the level of the district.

\section{Results - Who Pays and Who Refuses?}

\subsection{Bribery conditional on use of the official}

We begin by examining the determinants of a bribery episode, conditional on the official in the household-official pair having been used by the household. The marginal effects from these probits, multiplied by 100, are reported in Table 4. As in subsequent tables, each column contains results from a regression where the financial means of the household are represented by consumption (top panel), and from a second regression where they are represented by dummies for extreme and moderately poverty (middle panel). All regressions contain the basic controls: the travel time to the district administrative center and dummies for household size, town size, region and the 2003 survey.

Column 1 contains only the basic controls, while in column 2 we also control for whether the household visited the official twelve times ("monthly visits"), which changes the consumption-related coefficients little. The marginal effect of 0.740 in column 2 of the top panel indicates that a doubling of consumption (an increase of about one standard deviation) increases the probability of a bribery episode by $(0.0074)(\log 2)=0.0051$, or 0.5 percentage points. As would be expected if monthly visits involve simpler and more routine business, the dummy for monthly visits is significantly negative, indicating the monthly clients are 2.276 percentage points less likely to have a bribery episode. The middle panel indicates that the extremely poor have a 1.080 percentage point lower prob-

\footnotetext{
${ }^{22}$ Where the basic regression is a probit, we used the procedure for Stata developed by Joseph Harkness, available at http://ideas.repec.org/c/boc/bocode/s415801.html.
} 
ability of bribing than the non-poor. These effects are sizeable compared to the mean probability of a bribery episode of $2.3 \%$ in this sample.

The addition in column 3 of 20 dummies for the various official types greatly reduces the coefficients associated with consumption. In the top panel the marginal effect is reduced by two-thirds to 0.253 , while in the middle panel the effect falls by $53 \%$ to 0.512 percentage points. Thus, at least half of the greater propensity of the rich to bribe is because they disproportionately use official types that are generally more involved in bribery. Hunt (forthcoming) shows that such official types are characterized by slow service, as measured by business conclusion rates for non-corrupt dealings.

The addition of further groups of covariates in columns 4-6 of Table 4 yields consumptionrelated coefficients in column 6 similar to those in column 3: a doubling of consumption increases the probability of a bribery episode by 0.2 percentage points (marginal effect of 0.277$)$. The addition of characteristics of the respondent's job in column 5 affects the consumption-related coefficients little: the effect of consumption on bribery therefore does not principally reflect the types of jobs richer people have. ${ }^{23}$

Thus far, the analysis has not distinguished between types of bribery episode. We run unreported multinomial logits allowing the bribery episode to be split into the categories of bribed voluntarily, felt obliged to bribe, bribed because the official solicited a bribe, and refused to bribe. With only basic covariates, the point estimates suggest that there is a significant effect of consumption on all bribe categories relative to no bribery episode. Once (necessarily slightly aggregated) official type dummies are added, the coefficient for refusing a bribe becomes insignificant, but the coefficients for the different episode types are not significantly different from one another. ${ }^{24}$

The theoretical model, emphasizing the official as first mover, predicted that rich

\footnotetext{
${ }^{23}$ We do not control for the job types of other family members, as doing this reduces the sample size considerably. In general, however, characteristics of the respondent are much more significant than characteristics of other household members, suggesting the respondent underreports bribery episodes of other household members.

${ }^{24}$ Differences between types of episode will be understated, if, as seems likely, respondents succumb to the temptation to say that a voluntary bribe was in fact initiated by the official.
} 
clients would be more likely than poor to be solicited for a bribe, or feel obliged to bribe, and the results are consistent with this. The prediction for refusals relative to having no bribery episode was ambiguous. The effect of consumption on voluntary bribes points to an unmodelled role for consumption in leading clients to initiate a bribe.

\subsection{Use of officials}

In Table 5 we present the marginal effects of a probit for the relation between consumption and use of an official type, using the full household-official sample. Column 1 includes only basic covariates, and the top panel indicates that if household consumption is doubled, the probability of using an official rises by about $(0.045)(\log 2)=0.031$, or 3.1 percentage points. The middle panel indicates that the extremely poor have a 5.1 percentage point lower probability of using an official. These effects are large compared to the mean usage rate of $12.1 \%$ in this sample. Adding further covariates successively across the columns reduces the effect of doubling consumption to 1.7 percentage points in column 5 (marginal effect of 0.025 ), and reduces the effect of being extremely poor to 2.4 percentage points in column 5. About half the effect of consumption can therefore be explained by other covariates, but the effect remains substantial.

It is tempting to interpret the greater use of officials by richer households as reflecting

their generally greater demand for goods and services, but in fact we are unable to identify supply and demand separately: although we include geographic controls and travel time to the district administrative center, we cannot exclude the possibility that richer households have more public services available to them. We return in a later section to the possibility that corruption discourages households from using officials, and that this effect might be larger for the poor. The lack of a convincing exclusion restriction prevents us from directly examining the effect of expected bribes on usage. 


\subsection{Decomposition into use and bribery conditional on use}

Unconditionally, the rich have a higher incidence of bribery episodes: the gap between the non-poor and the extremely poor is 0.0025 in the household-official sample. The results of Tables 4 and 5 may be used to decompose this gap into components due to different usage and to different bribery conditional on usage.

The probability of bribing $P(B)$ is the product of the probability of using the official $P(O)$ and the probability of bribing the official conditional on use $P(B \mid O)$ :

$$
P_{j}(B)=P_{j}(O) P_{j}(B \mid O)
$$

where $j$ represents $N$, for non-poor, or $X P$, for extremely poor. The bribery gap between the non-poor and the extremely poor population is

$$
P_{N}(B)-P_{X P}(B)=P_{N}(O) P_{N}(B \mid O)-P_{X P}(O) P_{X P}(B \mid O),
$$

which can be rewritten as

$$
P_{N}(O) \Delta P(B \mid O)+P_{X P}(B \mid O) \Delta P(O)
$$

or

$$
P_{X P}(O) \Delta P(B \mid O)+P_{N}(B \mid O) \Delta P(O) .
$$

In the household-official data, the usage gap is 0.052 , and the gap in bribery conditional on usage is 0.013. Depending on whether the weighting of the usage and conditional bribery gaps is that of (22) or (23), the usage gap $\Delta P(O)$ contributes either $56 \%$ or only $30 \%$ to the overall bribery gap of 0.0025 .

At least $30 \%$ of the higher frequency of bribery episodes by the non-poor is therefore because they have a higher probability of using officials. Furthermore, of the remaining at most $70 \%$, the middle panel of Table 4 has shown that half is caused by the fact that the non-poor use more corrupt types of officials. Therefore, at most $35 \%$ of the higher bribery of the non-poor is owing to a higher probability of a bribery episode conditional on using a particular type of official. 


\section{Results - What Are the Payoffs?}

\subsection{Official's payoff: bribe amount}

In Table 6, for the sample of household-official pairs where a bribe was actually paid, we examine the determinants of the amount of the $(\log )$ bribe. Both panels of columns 1-6 indicate that, as predicted by the theoretical model, the official receives larger bribe amounts from richer clients. The top panel of column 1 indicates that the consumption elasticity of the bribe amount is 0.363 with only basic covariates included. The middle panel indicates that the extremely poor pay 52.7 log points less, or $43 \%$.

The marginal effects of the consumption-related covariates change little as additional covariates are added in columns 2-4. In particular, they are little affected by the addition of official type dummies in column 3: while rich people disproportionately use official types who have frequent bribery episodes, they do not disproportionately use official types who take large bribes. The addition of the "remaining covariates" in column 5 reduces the elasticity to 0.273 .

In column 6 we control for the type of bribery episode. Compared to the omitted bribe solicited by the official, those feeling obliged to bribe and especially those bribing voluntarily pay smaller bribes. This is also true when consumption (and most other covariates) are not controlled for, in column 7. Solicited bribes may be larger because they include a risk-premium for the official. Alternatively, the size of the bribe across categories may be related to the circumstances that lead to that category occurring.

The sample of bribe payers should yield information on whether the richer clients are paying more bribes for the same level of service (first degree price-discrimination) or whether the official offers richer clients packages of better service for a higher bribe (third degree price-discrimination). We can add controls to column 5 for our other measures of service: whether the business with the official was completed, the subjective assessment of the service quality (as two dummy variables) and whether the client was seen immedi-

ately. The inclusion of these variables changes the consumption-related coefficients little (these results are not reported), which would appear to be support for first-degree price- 
discrimination. However, the bribe amount is larger when the service is worse and the conclusion rate lower, which calls into question the validity of the test. ${ }^{25}$

\subsection{Client's payoff: quality of service}

In this section we investigate the payoff to the client of bribing or refusing to bribe, compared to dealing with an official acting honestly, while also allowing for the possibility of consumption having an independent effect on the payoff. We measure the payoff in terms of the quality of service, for which we have several measures. Our preferred measure is whether the client concluded her business with the official, which we believe represents speed of service. Marginal effects from probits for the probability of completion are presented in Table 7 .

The marginal effect of -0.016 in the top panel of the first column, where only basic controls are included, indicates that a doubling of household consumption actually reduces the probability of the client's concluding her business by a significant but small 1.1 percentage points (93\% of clients conclude their business in the twelve month window). The middle panel indicates that the extremely poor are 2.3 percentage points more likely to conclude their business. Monthly clients are more likely to conclude their business, by 4.3 percentage points in column 2 .

The inclusion of official type dummies in column 3 cuts the absolute value of the consumption-related coefficients approximately in half: richer clients appear to get slow service in part because they use officials who tend to give slow service, either because the officials of that type are of lower quality, or because they deal with more complicated and/or bureaucratic services. The consumption-related effects get slightly smaller as more covariates are included in columns $4-6$. We conclude that the rich are less likely to conclude their business, conditional on many controls, possibly because their business is more complex.

\footnotetext{
${ }^{25}$ Table 2 showed that service is worse when a client experiences a bribery episode than when she does not, and this relationship is discussed in the next section. The reasons for the amount of the bribe being higher when the service is worse are presumably similar.
} 
In column 6 we include dummy variables for whether the client experienced a bribery episode, distinguishing between the various bribery possibilities and refusal to bribe. As predicted by the model, the worst service is received by those who refuse to bribe: the probability of their concluding their business is 16.0 percentage points lower than that of those who had no bribery episode (and hence dealt with an official acting honestly). This marginal effect is significantly different from those for the other bribe categories.

However, those who felt obliged to bribe, or whom the official solicited for a bribe, still did significantly worse than those dealing with an honest official, by $2.8-4.8$ percentage points. This is supportive of endogeneity of the type predicted by the theoretical model: it is likely that the official provided slow service as a prelude to a bribe. The results indicate that the service loss from angling for a bribe is slightly more than the service gain provided in return for the bribe. For those who felt obliged to bribe, the results could additionally reflect that they had mistaken a naturally incompetent official for an official angling for a bribe. These results are consistent with those of Kaufmann and Wei (1999), who find that firms that commonly bribe spend more time on red tape, not less. The effects of different bribe types are similar when the sample is split into poor and non-poor households (results are not reported).

The theoretical model did not allow for voluntary bribes. Clients who value fast service more than the official can observe and who anticipate particularly slow service are likely to bribe voluntarily. For example, a client in a hurry who discovers a particularly long queue upon arriving in an office may seek out an official to bribe to jump the queue. The bribe may succeed in improving service, yet, given the bad initial situation, only bring service up to the normal level.

We can get an idea of how service is slowed by bribery by controlling for whether the official was seen immediately, in column 6 . Not surprisingly, seeing an official immediately increases the probability of concluding business, by 11.6 percentage points. More interestingly, adding this control reduces each of the bribery episode coefficients by at least $30 \%$, and reduces the gap between the refusals and the other bribery categories. This suggests that a weapon in the arsenal of the corrupt official, both as a signal and a punishment, 
is delaying seeing a client. It also hints at a role for bribing gatekeepers to gain access to the officials with power. In column 7 we show that the bribery effects of column 5 are little affected by the presence or absence of other covariates.

Since seeing an official immediately or not seems to play a role in bribery, and may even be the outcome a bribe payer is trying to influence (jumping the queue), we examine this outcome directly in columns 1 and 2 of Table 8, controlling for all household and respondent characteristics. Poor and monthly clients are statistically significantly more likely to see an official immediately (the extreme poor by 1.3-1.4 percentage points and monthly clients by $2.1-2.2$ percentage points, compared to a mean of $93 \%$ ). Unreported coefficients for income are insignificant.

The marginal effects on the types of bribery episode in column 2 mirror the case of concluded business in Table 7: those involved in bribery are statistically significantly less likely to see an official immediately, compared to clients engaged in non-corrupt dealings, and especially so for those who refuse to bribe. Clients who refuse to bribe are 17 percentage points less likely to see an official immediately, a statistically significantly worse outcome than for the three types of clients who do bribe. Those paying bribes solicited by the official are statistically significantly worse off than voluntary bribe payers with a ten percentage point disadvantage, similar to the nine percentage point disadvantage of those feeling obliged to bribe. Voluntary bribe payers are 5.8 percentage points less likely to see an official immediately than clients dealing with an official acting honestly.

We perform a similar exercise for the probability of the service being assessed as bad (columns 3-5) and good (columns 6-8). Richer clients appear to be more likely to have bad or good service. The marginal effects for the bribery categories have a familiar pattern (columns 4 and 7): those involved in bribery are worse off, while among this group, clients refusing to bribe are worst off and voluntary bribe payers are best off. The pattern is more pronounced for bad service than good. Controlling for the more objective service measures, whether the official was seen immediately and whether the business was concluded, has little effect on the relevant marginal effects for good service (column 8), but greatly reduces the absolute value of the effect on bad service of refusing to bribe, from 
0.37 to 0.25 in column 5 . Clients refusing to bribe perceive their service as particularly bad in part because they have been punished with slow access to the official and slow subsequent service.

\section{Is Bribery a Regressive Tax?}

The insights of the preceding sections can be combined with some simple additional statistics to assess whether bribery can be considered to be a regressive tax, or a larger burden on the poor than the rich. We will analyze users of officials, and speculate on how to generalize to the whole population. We cannot judge whether bribery skews growth in favor of the rich, however.

Among users of officials, the rich bribe more frequently, and pay higher bribes, and the distribution of types of bribery episode is the same for rich and poor. The burden of bribery can therefore only be higher for the poor when considered relative to income. This is demonstrated in column 1 of Table 9, which presents expected bribes - average bribes including zeroes - by poverty status, for household-official pairs where the official is used. Extremely poor clients can expect to pay a bribe of 0.30 Nuevos Soles, compared to 0.67 Nuevos Soles for the moderately poor and 1.63 Nuevos Soles for the non-poor. In column 2 the expected bribe is calculated by averaging over (annual) bribes as a share of household quarterly consumption (and multiplying by 1000). The "tax rate" on the extremely poor and moderately poor is $0.025 \%$, while it is $0.035 \%$ for the non-poor, and the tax is therefore progressive.

Since the poverty indicators are based on consumption, and consumption may be measured with error, the tax rate may be more progressive than it appears in column $2 .{ }^{26}$ To avoid this problem, we also compute the expected bribe as a share of income (in column 3). The differences between columns 2 and 3 are not consistent with successful correction of measurement error, as the tax is less progressive when income is used in

\footnotetext{
${ }^{26}$ Consider a poor household whose recorded consumption is erroneously high, causing the household to be measured as non-poor and have an underestimated tax rate. The mistake in the household's consumption biases the non-poor tax rate down.
} 
column 3 .

The results of Table 9 suggest that the bribery tax is a progressive, or at worst flat, tax. Using results at the household level, aggregated over official types, only makes the bribery tax appear more progressive, since the rich use many more officials (column 4 of Table 9 shows the usage probabilities at the household-official level). The share of expected (annual) bribe payments in quarterly consumption, calculated at the household level, is $0.72 \%$ for the extremely poor, $0.75 \%$ for the moderately poor, and $1.20 \%$ for the non-poor. These shares are somewhat progressive.

We cannot judge, however, how progressive the tax on consumption should be to ensure the tax on household welfare is progressive. To assess the progressiveness of the welfare tax, we exploit the survey question asking users whether they wasted significant time or money in connection with their business with the official. ${ }^{27}$ We view this as a proxy for the respondent's perceived burden of using the official, and we tabulate this by poverty status in Table 10. Households who had a bribery episode were much more likely to have wasted time or money than those who had none ( $83 \%$ in column 2 compared with $46 \%$ in column 1). If bribery is a greater burden on the poor, this gap should be larger for the poor. Yet, column 3 shows that the gap is smaller for the extreme poor $(0.31)$ than for the non-poor $(0.37)$, though the difference is not statistically significant. These results are robust to moving those refusing to bribe from the bribery episode column to the no bribery column, to moving voluntary briber payers to the no bribery column, and to moving the analysis to a regression framework and adding covariates (not reported).

Thus, among users of public officials, bribery is at worst a flat tax. Some households may be discouraged from using officials because of the prospect of having to bribe. Lacking an appropriate exclusion restriction, we have not been able to examine this directly. If the poor constitute more of the discouraged, or if discouragement is more costly for the poor, the burden of bribery on non-users could conceivably be regressive. However, the evidence that the bribery burden for users is flat suggests to us that any differential discouragement effect must be small. We therefore consider it unlikely that the burden of

27 " ¿Le ocasionó pérdida de tiempo y/o gasto significativo en transporte u otros?" 
bribery is regressive for the whole population. We have not excluded the possibility that the rich pay more in part because they receive more, however.

\section{Conclusions}

We have used theory and detailed data on households' use and bribery of public officials in Peru to build a framework describing the determinants of bribery, and the payoffs to bribery. We establish empirically that officials discriminate between clients on the basis of income when deciding whether to angle for a bribe and how much to ask for. Rich clients pay more frequent and larger bribes than poor clients. Our results suggest that officials practice first-degree price discrimination rather than third-degree price discrimination, but are not conclusive on this point. Overall, even as a share of income, rich clients' spending on bribes is as much as or more than that of poor clients.

Most of the gap in the exposure of the rich and poor to bribery does not stem from differences among clients of the same type of public official, however. At least $30 \%$ of the bribery episode gap between the extreme poor and the non-poor is explained by the greater use of officials by the non-poor. This is likely the result of greater demand for public services by the non-poor. Furthermore, at least another $35 \%$ of the gap is explained by the fact that the non-poor use a more corrupt mix of official types. Therefore, at most $35 \%$ of the gap is owing to a higher probability of bribery for the non-poor conditional on using a particular official type. Doubling a client's value of consumption increases this probability by 0.2 percentage points, compared to a bribery episode probability in the relevant sample of $2.3 \%$.

The client's payoff to bribing is merely the recouping of most of the time lost while the official was angling for a bribe by shirking. Refusal to bribe is punished by further shirking on the official's part and results in the worst possible service for the client. Some of the shirking and angling takes the form of refusing to see the client. In a minority of cases

involving richer clients, the client bribes voluntarily, which yields service comparable to that enjoyed by clients engaged in non-corrupt dealings. These voluntary bribes may be 
provoked by the anticipation of particularly bad service, and may be effective in bringing the service up to the normal standard.

The tax imposed by bribery, whether measured as the share of expected bribes in consumption, or as the gap in time or money wasted between clients of unscrupulous and scrupulous officials, is not regressive for users of officials. Given this, we think it unlikely that any differential deterrence effect of bribery on use by the poor and non-poor would be large enough to make the tax regressive for the whole population. The main distributional consequence of bribery appears to be a transfer from clients to officials in return for no net improvement in service. 


\section{References}

[1] Aidt, Toke. "Economic Analysis of Corruption: a Survey". Economic Journal, Vol.113 (November 2003): F632-F652.

[2] Andvig, Jens Christian and Karl Ove Moene. "How Corruption May Corrupt". Journal of Economic Behavior and Organization, Vol.13 (1990): 63-76.

[3] Banerjee, Abhijit. "A Theory of Misgovernance". Quarterly Journal of Economics, Vol.112 (4) (1997): 289-1332.

[4] Bertrand, Marianne, Simeon Djankov, Rema Henna and Sendhil Mullainathan. "Obtaining a Driving License in India: An Experimental Approach to Studying Corruption", MIT Working Paper, 2005.

[5] Cadot, Olivier. "Corruption as a Gamble". Journal of Public Economics, Vol.33 (1987): 223-44.

[6] Choi, Jay Pil and Marcel Tham. "The Economics of Repeated Extortion". RAND Journal of Economics, Vol.35 (2) (Summer 2004): 203-223.

[7] Deininger, Klaus and Paul Mpuga. "Does Greater Accountability Improve the Quality of Public Service Delivery? Evidence from Uganda". World Development Vol.33 (1) (2004): 171-191.

[8] Di Tella, Rafael and Ernesto Schargrodsky. "The Role of Wages and Auditing During a Crackdown on Corruption in the City of Buenos Aires". Journal of Law and Economics, Vol.1 (April 2003): 269-292.

[9] Fisman, Raymond and Roberta Gatti. "Decentralization and Corruption: Evidence Across Countries". Journal of Public Economics, Vol.83 (2002): 325-345.

[10] Gupta Sanjeev, Hamid Davoodi and Rosa Alonso-Terme. "Does Corruption Affect Income Inequality and Poverty?". Economics of Governance, Vol.3 (2002): 23-45.

[11] Hunt, Jennifer. "Trust and Bribery: The Role of the Quid Pro Quo and the Link with Crime". National Bureau of Economic Research, NBER working paper 10510, 2004.

[12] Hunt, Jennifer. "Why Are Some Public Officials More Corrupt Than Others?". In Susan Rose-Ackerman ed. Handbook of Economic Corruption, Cheltenham: Edward Elgar, forthcoming.

[13] Kaufmann, Daniel, Sanjay Pradhan and Randi Ryterman. "New Frontiers in Diagnosing and Combating Corruption". World Bank PREM Notes: Public Sector, October (1998). 
[14] Kaufmann, Daniel and Shang-Jin Wei. "Does 'Grease Money' Speed Up the Wheels of Commerce?". National Bureau of Economic Research, NBER working paper 7093, 1999.

[15] Lui, Francis. "An Equilibrium Queuing Model of Bribery". Journal of Political Economy, Vol.93(4) (1985): 760-81.

[16] Mauro, Paolo. "Corruption and Growth". Quarterly Journal of Economics, Vol.110(3) (1995): 681-712.

[17] McMillan, John and Pablo Zoido. "How to Subvert Democracy: Montesinos in Peru". Journal of Economic Perspectives, Vol.18(4) (Fall 2004): 69-92.

[18] Mookherjee, Dilip and Ivan Png. "Corruptible Law Enforcers: How Should They be Compensated?". Economic Journal, Vol.105(127) (1995): 145-59.

[19] Olson, Mancur Jr., Naveen Sarna and Anand Swamy. "Governance and Growth: A Simple Hypothesis Explaining Cross-Country Differences in Productivity Growth". Public Choice, Vol.102 (2000): 341-64.

[20] Prendergast, Canice. "Selection and Oversight in the Public Sector, with the Los Angeles Police Department as an Example". National Bureau of Economic Research, NBER working paper 8664, 2001.

[21] Proética. "Segunda Encuesta Nacional Sobre Corrupción". APOYO Opinión Y Mercado. Lima: APOYO, 2003.

[22] Proética. "Tercera Encuesta Nacional Sobre Corrupción". APOYO Opinión Y Mercado. Lima: APOYO, 2004.

[23] Rose-Ackerman, Susan. "The Economics of Corruption". Journal of Public Economics, Vol.4 (1975): 187-203.

[24] Rose-Ackerman, Susan. Corruption: A Study in Political Economy. New York: Academic Press, 1978.

[25] Sah, Raaj Kumar. "Persistence and Pervasiveness of Corruption: New Perspectives". Yale Economic Growth Center Discussion Paper No. 560, August 1988.

[26] Shleifer, Andrei and Robert W. Vishny. "Corruption". Quarterly Journal of Economics, Vol.109 (August 1993): 599-617.

[27] Svensson, Jakob. "Who Must Pay Bribes and How Much? Evidence From A Cross Section of Firms". Quarterly Journal of Economics, Vol.118 (February 2003): 207-30.

[28] Swamy, Anand, Stephen Knack, Young Lee and Omar Azfar. "Gender and Corruption". Journal of Development Economics, Vol.64 (2001): 25-55. 
[29] Transparency International. "Country Report on the National Integrity System in Peru". (In Spanish) Report prepared by Instituto APOYO for Transparency International. Lima: APOYO/Transparency International, 2001a.

[30] Transparency International. "Country Report on the National Integrity System in Peru". (In Spanish) Questionnaire for report prepared by Instituto APOYO for Transparency International. Lima: APOYO/Transparency International, 2001b.

[31] Transparency International. "Corruption continues to deprive societies around the world". Press Release (20 October 2004), http://www.icgg.org/downloads/ (Retrieved 16 December 2004) Berlin: Transparency International, 2004a.

[32] Transparency International. "Report on the Transparency International Global Barometer 2004". Policy and Research Department. Berlin: Transparency International, 2004b.

[33] Treisman, Daniel. "The Causes of Corruption: A Cross-National Study". Journal of Public Economics, Vol.76 (3) (2000): 399-457.

[34] World Bank. "Peru Institutional Governance Review". World Bank Peru Governance Diagnostics. Washington: World Bank, 2001a.

[35] World Bank. Memorandum of the President of the International Bank for Reconstruction and Development to the Executive Directors on a Country Assistance Strategy: Progress Report of the World Bank Group for Peru. Bolivia, Ecuador and Peru Country Management Unit. Washington: World Bank, 2001b. 


\section{Data Appendix}

\subsection{General}

The 2002 survey was taken in October, November and December of 2002. The "2003" survey was taken from May 2003 to April 2004. One quarter of the 2003 households were also interviewed in 2002. We simply combine monetary values from surveys taken at different times with no adjustment for inflation or seasonality, which tests indicated was appropriate for household consumption. A noteworthy discrepancy between 2002 and 2003 is a leap in the share of households reporting in the bribery module that they had used a state hospital, something contradicted by the health module. Whenever we control for official type dummies, we therefore also permit an interaction of the state hospital dummy with a dummy for the survey year 2003.

\subsection{Official types}

The twenty-one types of official listed in the survey are: municipal (city) government, social security (providing social insurance other than pensions), state banks, judiciary, drinking water, telephone, electricity, state schools, arbitration, Ministry of Agriculture, Ministry of Industry, tax/customs authority, state hospitals, national civil identification registry, Department of Migration, police, electoral office, electoral court, development agency, food agency, and "other".

\subsection{Is the bribery rate plausible?}

Columns 1 and 2 of Table 1 show $4.9 \%$ of households, and $5.7 \%$ of households using at least one official, reported having bribed (or tipped etc.) or refused to bribe in the previous twelve months (a bribery "episode"). Although the share of households experiencing a bribery episode may seem low, the bribery episode rates for some official types are very high (37\% for the police), indicating that, at least for some official types, respondents were not ashamed or afraid to acknowledge a bribery episode. The stigma associated with bribery in Peru is not large: Proética, a Peruvian anti-corruption group, found that when asked to define the Peruvian slang for bribe ("coima"), less than half their survey respondents gave answers with a negative connotation. ${ }^{28}$ Furthermore, the Peruvian household survey does not attempt to force respondents to admit to having voluntarily paid a bribe, but allows them merely to acknowledge having paid a tip under duress. We are therefore not concerned that reluctance to report is a major issue.

The share of households bribing and the number of bribes will be understated if clients commonly use agents to act as intermediaries between themselves and officials, and bribes paid by the agent are reported in the survey by the agent (or no-one), rather than the client. A 2003 survey by Proética gathered information on bribes and agents ("tramita-

\footnotetext{
${ }^{28}$ Proética (2004).
} 
dores"). ${ }^{29} 52 \%$ of respondents who had bribed to obtain a driver's licence reported having paid the bribe to an agent, while the share was $15 \%$ or less for the other nine activities reported in the summary statistics. ${ }^{30}$ The number of bribery episodes per household is understated owing to the fact that each respondent can only report one bribery episode per official per year.

A 2004 Transparency International survey of 416 respondents in greater Lima found $14 \%$ of respondents had bribed in the previous twelve months, compared to 6.0 per cent among the 3758 Lima respondents in our 2002-2003 data. ${ }^{31}$ However, the Transparency question did not restrict itself to bribes paid to public officials. Proética reports much higher bribery rates for the years 2002, 2003 and 2004 of $32 \%, 29 \%$ and $27 \%$, respectively. ${ }^{32}$ Proética's bribery rates, conditional on the use of particular officials, look very similar to those in our data, but their usage rates look implausibly high for a window of one year. This suggests that the Proética time frame, not reported in the documentation available to us, was in fact much longer than a year, even though yearly bribery rates are reported.

Taking the various factors into consideration, it seems inevitable that our survey somewhat underestimates bribery of public officials, but we do not believe the underestimation to be severe. We prefer our survey to the Transparency and Proética surveys because of its large sample, wealth of covariates and additional questions on the bribery and usage of public officials.

\footnotetext{
${ }^{29}$ Proética (2003).

${ }^{30}$ Bertrand et al. (2005) analyze the use of agents for obtaining drivers' licences in India.

${ }^{31}$ Transparency (2004b).

${ }^{32}$ Proética (2004).
} 
Table 1: Characteristics of bribery in previous 12 months - household level (Standard deviations in parentheses)

\begin{tabular}{|lcccc|}
\hline & $\begin{array}{c}(1) \\
\text { Full sample }\end{array}$ & $\begin{array}{c}(2) \\
\text { Used an official }\end{array}$ & $\begin{array}{c}(3) \\
\text { Bribery episode }\end{array}$ & $\begin{array}{c}(4) \\
\text { Reported } \\
\text { amount bribe }\end{array}$ \\
\hline Bribery episode & 0.049 & 0.057 & 1 & 1 \\
Number of bribery episodes & -- & -- & 1.20 & 1.22 \\
& & & $(0.52)$ & $(0.54)$ \\
Used an official & 0.87 & 1 & 1 & 1 \\
Used police & 0.05 & 0.06 & 0.47 & 0.49 \\
Used school official & 0.54 & 0.63 & 0.59 & 0.60 \\
Number of types of officials & 2.5 & 3.0 & 4.5 & 4.6 \\
used & $(2.0)$ & $(1.8)$ & $(2.4)$ & $(2.4)$ \\
Total visits to officials & 13.0 & 15.2 & 22.7 & $(21.2)$ \\
& $(15.4)$ & $(15.6)$ & $(20.9)$ & 78 \\
Value of bribes paid by & -- & -- & -- & $(462)$ \\
household (Nuevos Soles) & & & & 4940 \\
Household quarterly & 3656 & 3869 & 5025 & $(5372)$ \\
consumption (Nuevos Soles) & $(4551)$ & $(4694)$ & $(5808)$ & 0.020 \\
Bribe value/quarterly & -- & -- & -- & $(0.08)$ \\
consumption & & & & 0.09 \\
Extreme poverty & 0.20 & 0.20 & 0.09 & 0.23 \\
Moderate poverty & 0.27 & 0.27 & 0.22 & 1,415 \\
\hline Observations & 36,080 & 30,889 & 1,774 & \\
\hline
\end{tabular}

Notes: The unit of observation is the household. A household is included if information on at least one official type is complete. One Nuevo Sol is worth about 30 U.S. cents. 
Table 2: Characteristics of bribery in previous 12 months - household-official level (Standard deviations in parentheses)

\begin{tabular}{|lcccc|}
\hline & $\begin{array}{c}(1) \\
\text { Full sample }\end{array}$ & $\begin{array}{c}(2) \\
\text { Used an } \\
\text { official }\end{array}$ & $\begin{array}{c}(3) \\
\text { Bribery } \\
\text { episode }\end{array}$ & $\begin{array}{c}\text { Reported } \\
\text { amount bribe }\end{array}$ \\
\hline Bribery episode & 0.0028 & 0.023 & 1 & 1 \\
Bribery: official solicited bribe & -- & -- & 0.48 & 0.61 \\
Bribery: felt obliged to bribe & -- & -- & 0.22 & 0.28 \\
Bribery: bribed voluntarily & -- & -- & 0.08 & 0.10 \\
Bribery: refused to bribe & -- & -- & 0.22 & 0 \\
Used official & 0.121 & 1 & 1 & 1 \\
Visits to official & -- & 5.1 & 4.9 & 4.8 \\
Share with twelve visits & -- & 0.21 & 0.03 & 0.03 \\
Concluded business with official & -- & 0.93 & 0.74 & 0.78 \\
Official service good & -- & 0.33 & 0.09 & 0.10 \\
Official service regular & -- & 0.57 & 0.39 & 0.40 \\
Official service bad & -- & 0.09 & 0.52 & 0.50 \\
Saw official immediately & -- & 0.95 & 0.73 & 0.75 \\
Value of bribe & -- & -- & -- & 67 \\
& & & & $(423)$ \\
Bribe value/quarterly & -- & -- & -- & 0.017 \\
consumption & & & & $(0.08)$ \\
\hline Observations & 757,461 & 91,668 & 2,123 & 1,628 \\
\hline
\end{tabular}

Notes: The unit of observation is the household-official pair. 
Table 3: Distribution of bribery episodes across official types

\begin{tabular}{|c|c|c|c|c|c|}
\hline Official type & $\begin{array}{c}\text { (1) } \\
\text { Number } \\
\text { of bribery } \\
\text { episodes }\end{array}$ & $\begin{array}{c}(2) \\
\text { Share } \\
\text { of bribery } \\
\text { episodes }\end{array}$ & $\begin{array}{c}(3) \\
\text { Share of } \\
\text { amount of } \\
\text { bribe } \\
\text { payments }\end{array}$ & $\begin{array}{c}\text { (4) } \\
\text { Share of } \\
\text { households } \\
\text { using official } \\
\text { type }\end{array}$ & $\begin{array}{c}\text { (5) } \\
\text { Share of } \\
\text { officials with } \\
\text { bribery } \\
\text { episode }\end{array}$ \\
\hline Police & 738 & 0.35 & 0.27 & 0.06 & 0.372 \\
\hline Municipal government & 447 & 0.21 & 0.11 & 0.26 & 0.048 \\
\hline Judicial system & 245 & 0.12 & 0.42 & 0.04 & 0.165 \\
\hline Schools & 165 & 0.08 & 0.05 & 0.54 & 0.008 \\
\hline $\begin{array}{l}\text { Utilities (sum of water, } \\
\text { phone, electricity) }\end{array}$ & 107 & 0.05 & 0.01 & 0.42 & 0.004 \\
\hline State hospitals & 95 & 0.04 & 0.02 & 0.34 & 0.008 \\
\hline National ID Registry & 78 & 0.04 & 0.02 & 0.16 & 0.013 \\
\hline Other & 248 & 0.12 & 0.10 & 0.28 & 0.018 \\
\hline Total & 2,123 & 1 & 1 & -- & 0.023 \\
\hline Observations & 2,123 & 2,123 & 1,628 & See notes & 91,668 \\
\hline
\end{tabular}

Notes: The 21 official types have been collapsed to fewer categories for this table. 36,080 households contribute to the calculations of column 4, but a few households are missing from each row, as not all households have valid information for all official types. 
Table 4: Determinants of bribery episode conditional on use of official (Marginal effects multiplied by 100; t-statistics in parentheses)

\begin{tabular}{|c|c|c|c|c|c|c|}
\hline & $(1)$ & $(2)$ & $(3)$ & $(4)$ & $(5)$ & $(6)$ \\
\hline Log household & 0.772 & 0.740 & 0.253 & 0.213 & 0.223 & 0.277 \\
\hline consumption & $(7.5)$ & $(8.5)$ & $(4.5)$ & $(3.3)$ & $(3.4)$ & $(4.0)$ \\
\hline \multirow[t]{2}{*}{ Monthly visits } & \multirow[t]{2}{*}{--} & -2.276 & -0.594 & -0.594 & -0.582 & -0.556 \\
\hline & & $(-14.8)$ & $(-4.5)$ & $(-4.5)$ & $(-4.5)$ & $(-4.5)$ \\
\hline \multirow{2}{*}{$\begin{array}{l}\text { Respondent education } \\
\text { years }\end{array}$} & \multirow[t]{2}{*}{--} & \multirow[t]{2}{*}{--} & \multirow[t]{2}{*}{--} & 0.014 & 0.020 & -0.005 \\
\hline & & & & $(1.5)$ & $(2.1)$ & $(-0.5)$ \\
\hline Household & -1.147 & -1.080 & -0.512 & -0.476 & -0.454 & -0.493 \\
\hline extremely poor & $(-5.9)$ & $(-6.5)$ & $(-4.9)$ & $(-4.2)$ & $(-4.1)$ & $(-4.4)$ \\
\hline Household & -0.616 & -0.623 & -0.271 & -0.241 & -0.245 & -0.292 \\
\hline moderately poor & $(-4.5)$ & $(-5.3)$ & $(-3.5)$ & $(-2.8)$ & $(-2.8)$ & $(-3.5)$ \\
\hline $\begin{array}{l}20 \text { official type } \\
\text { dummies }\end{array}$ & -- & -- & Yes & Yes & Yes & Yes \\
\hline Respondent job type & -- & -- & -- & -- & Yes & Yes \\
\hline Remaining covariates & -- & -- & -- & -- & -- & Yes \\
\hline R-squared & 0.02 & 0.04 & 0.27 & 0.27 & 0.27 & 0.27 \\
\hline
\end{tabular}

Notes: Probit regressions with t-statistics clustered by district. 91,668 observations. The two panels of coefficients are from two different regressions. The R-squared is the same in each panel. All regressions include seven regional dummies, household size dummies, town size dummies, time to the district administrative center and a dummy for the 2003 survey. "Job type" dummies for the respondent's main job are employer (non-agricultural), employer (agricultural), employer*employs more than ten employees, selfemployed (non-agricultural), self-employed (agricultural), white collar, blue collar, domestic worker, unpaid family member and other (the omitted type is respondent not working). "Remaining covariates" consist of characteristics of the respondent (sex, married/cohabiting, married/cohabiting*sex, age and age squared, student status, whether main job is in military/police, or public administration) and of the household (number of earners, ownership dummies for bicycle, car/van, tricycle, motorbike, and truck, whether land obtained by invasion, presence of children aged 0-3, 3-7, 8-11 and 12-15). When official types are controlled for, the interaction state hospital 2003 survey is also included. 
Table 5: Probability of using an official (Marginal effects; t-statistics in parentheses)

\begin{tabular}{|lccccc|}
\hline & $(1)$ & $(2)$ & $(3)$ & $(4)$ & $(5)$ \\
\hline Log household & 0.045 & 0.033 & 0.027 & 0.026 & 0.025 \\
consumption & $(29.7)$ & $(29.9)$ & $(24.9)$ & $(24.2)$ & $(23.2)$ \\
Respondent & -- & -- & 0.002 & 0.002 & 0.002 \\
education years & & & $(20.7)$ & $(19.0)$ & $(16.8)$ \\
\hline Household & -0.051 & -0.036 & -0.028 & -0.027 & -0.024 \\
extremely poor & $(-27.7)$ & $(-27.9)$ & $(-22.9)$ & $(-22.2)$ & $(-19.6)$ \\
Household & -0.034 & -0.025 & -0.019 & -0.018 & -0.015 \\
moderately poor & $(-26.3)$ & $(-27.1)$ & $(-21.5)$ & $(-20.0)$ & $(-17.3)$ \\
\hline 20 official type & -- & Yes & Yes & Yes & Yes \\
dummies & & & & & Yes \\
Respondent job type & -- & -- & -- & -- & Yes \\
Remaining covariates & -- & -- & --31 & 0.31 & 0.31 \\
R-squared & 0.04 & 0.30 & 0.31 & & \\
\hline
\end{tabular}

Notes: Probit regressions with t-statistics clustered by district. 757,461 observations. The two panels of coefficients are from two different regressions. The reported R-squared is for the top panel, but the Rsquared for the middle panel is very similar. See notes to Table 4 for a description of the covariates. 
Table 6: Determinants of $\log$ bribe value (T-statistics in parentheses)

\begin{tabular}{|c|c|c|c|c|c|c|c|}
\hline & $(1)$ & $(2)$ & $(3)$ & $(4)$ & $(5)$ & $(6)$ & $(7)$ \\
\hline Log household & 0.363 & 0.360 & 0.331 & 0.329 & 0.268 & 0.273 & -- \\
\hline consumption & $(5.0)$ & $(5.0)$ & $(5.1)$ & $(4.6)$ & $(3.2)$ & $(3.3)$ & \\
\hline \multirow[t]{2}{*}{ Monthly visits } & -- & 0.141 & 0.234 & 0.241 & 0.292 & 0.286 & 0.269 \\
\hline & & $(0.5)$ & $(1.2)$ & $(1.2)$ & $(1.4)$ & $(1.5)$ & $(1.3)$ \\
\hline $\begin{array}{l}\text { Respondent education } \\
\text { years }\end{array}$ & -- & -- & -- & $\begin{array}{l}-0.006 \\
(-0.7)\end{array}$ & $\begin{array}{c}0.002 \\
(0.2)\end{array}$ & $\begin{array}{c}0.005 \\
(0.5)\end{array}$ & -- \\
\hline Felt obliged to bribe & -- & -- & -- & -- & -- & -0.294 & $\begin{array}{r}-0.254 \\
-32\end{array}$ \\
\hline Bribed voluntarily & -- & -- & -- & -- & -- & $\begin{array}{l}-0.516 \\
(-5.3)\end{array}$ & $\begin{array}{l}-0.493 \\
(-4.7)\end{array}$ \\
\hline $\begin{array}{l}\text { Household } \\
\text { extremely poor }\end{array}$ & $\begin{array}{l}-0.527 \\
(-3.5)\end{array}$ & $\begin{array}{l}-0.520 \\
(-3.5)\end{array}$ & $\begin{array}{l}-0.506 \\
(-3.5)\end{array}$ & $\begin{array}{l}-0.492 \\
(-3.3)\end{array}$ & $\begin{array}{l}-0.422 \\
(-2.8)\end{array}$ & $\begin{array}{l}-0.412 \\
(-2.9)\end{array}$ & -- \\
\hline Household & -0.306 & -0.302 & -0.294 & -0.282 & -0.218 & -0.217 & -- \\
\hline moderately poor & $(-3.1)$ & $(-3.1)$ & $(-3.1)$ & $(-2.8)$ & $(-2.0)$ & $(-2.0)$ & \\
\hline $\begin{array}{l}20 \text { official type } \\
\text { dummies }\end{array}$ & -- & -- & Yes & Yes & Yes & Yes & Yes \\
\hline Respondent job type & -- & -- & -- & Yes & Yes & Yes & -- \\
\hline Remaining covariates & -- & -- & -- & -- & Yes & Yes & -- \\
\hline R-squared & 0.04 & 0.04 & 0.15 & 0.16 & 0.18 & 0.19 & 0.15 \\
\hline
\end{tabular}

Notes: OLS regressions with t-statistics clustered by district. 1628 observations. The two panels of coefficients are from two different regressions. The reported R-squared is for the top panel, but the Rsquared for the middle panel is very similar. See notes to Table 4 for a description of the covariates. The omitted bribe type in columns 6 and 7 is one solicited by the official. 
Table 7: Determinants of probability of successfully concluding business with official (Marginal effects; t-statistics in parentheses)

\begin{tabular}{|c|c|c|c|c|c|c|c|}
\hline & $(1)$ & $(2)$ & (3) & $(4)$ & (5) & $(6)$ & $(7)$ \\
\hline Log household & -0.016 & -0.018 & -0.008 & -0.007 & -0.007 & -0.005 & -- \\
\hline consumption & $(-6.7)$ & $(-7.3)$ & $(-3.6)$ & $(-3.2)$ & $(-3.0)$ & $(-2.4)$ & \\
\hline \multirow[t]{2}{*}{ Monthly visits } & \multirow[t]{2}{*}{--} & 0.043 & 0.025 & 0.025 & 0.025 & 0.023 & 0.025 \\
\hline & & $(3.4)$ & $(2.3)$ & $(2.3)$ & $(2.3)$ & $(2.1)$ & $(2.2)$ \\
\hline \multirow{2}{*}{$\begin{array}{l}\text { Respondent } \\
\text { education years }\end{array}$} & \multirow[t]{2}{*}{--} & \multirow[t]{2}{*}{--} & \multirow[t]{2}{*}{--} & -0.000 & -0.000 & -0.000 & -- \\
\hline & & & & $(-1.3)$ & $(-1.3)$ & $(-1.0)$ & \\
\hline \multirow{2}{*}{$\begin{array}{l}\text { Bribe solicited by } \\
\text { official }\end{array}$} & \multirow[t]{2}{*}{--} & \multirow[t]{2}{*}{--} & \multirow[t]{2}{*}{--} & \multirow[t]{2}{*}{--} & -0.048 & -0.029 & -0.048 \\
\hline & & & & & $(-7.1)$ & $(-4.7)$ & $(-7.0)$ \\
\hline \multirow{4}{*}{$\begin{array}{l}\text { Felt obliged to } \\
\text { bribe } \\
\text { Bribed voluntarily }\end{array}$} & \multirow[t]{2}{*}{--} & \multirow[t]{2}{*}{--} & \multirow[t]{2}{*}{--} & \multirow[t]{2}{*}{--} & -0.028 & -0.014 & -0.029 \\
\hline & & & & & $(-3.0)$ & $(-1.7)$ & $(-3.0)$ \\
\hline & \multirow[t]{2}{*}{--} & \multirow[t]{2}{*}{--} & \multirow[t]{2}{*}{--} & \multirow[t]{2}{*}{--} & -0.016 & -0.010 & -0.016 \\
\hline & & & & & $(-1.0)$ & $(-0.6)$ & $(-1.0)$ \\
\hline \multirow[t]{2}{*}{ Refused to bribe } & \multirow[t]{2}{*}{--} & \multirow[t]{2}{*}{--} & \multirow[t]{2}{*}{--} & \multirow[t]{2}{*}{--} & -0.160 & -0.112 & -0.160 \\
\hline & & & & & $(-9.7)$ & $(-8.0)$ & $(-9.6)$ \\
\hline \multirow{2}{*}{$\begin{array}{l}\text { Saw official } \\
\text { immediately }\end{array}$} & \multirow[t]{2}{*}{--} & \multirow[t]{2}{*}{--} & \multirow[t]{2}{*}{--} & \multirow[t]{2}{*}{--} & \multirow[t]{2}{*}{--} & 0.116 & \multirow[t]{2}{*}{--} \\
\hline & & & & & & $(23.6)$ & \\
\hline \multirow{4}{*}{$\begin{array}{l}\text { Household } \\
\text { extremely poor } \\
\text { Household } \\
\text { moderately poor }\end{array}$} & 0.023 & 0.025 & 0.012 & 0.010 & 0.009 & 0.008 & - \\
\hline & $(6.2)$ & $(7.0)$ & $(3.7)$ & $(2.8)$ & $(2.7)$ & $(2.2)$ & \\
\hline & 0.016 & 0.018 & 0.010 & 0.009 & 0.008 & 0.007 & -- \\
\hline & $(5.4)$ & $(6.5)$ & $(4.1)$ & $(3.0)$ & $(2.9)$ & $(2.6)$ & \\
\hline $\begin{array}{l}20 \text { official type } \\
\text { dummies }\end{array}$ & -- & -- & Yes & Yes & Yes & Yes & Yes \\
\hline $\begin{array}{l}\text { Respondent job } \\
\text { type }\end{array}$ & -- & -- & -- & Yes & Yes & Yes & -- \\
\hline $\begin{array}{l}\text { Remaining } \\
\text { covariates }\end{array}$ & -- & -- & -- & Yes & Yes & Yes & -- \\
\hline R-squared & 0.02 & 0.03 & 0.11 & 0.11 & 0.11 & 0.13 & 0.11 \\
\hline
\end{tabular}

Notes: Probit regressions with t-statistics clustered by district. 91,668 observations. The two panels of coefficients are from two different regressions. The R-squared is the same in each panel. See notes to Table 4 for a description of the covariates. 
Table 8: Determinants of further service measures

( $T$-statistics in parentheses)

\begin{tabular}{|c|c|c|c|c|c|c|c|c|}
\hline \multirow{5}{*}{$\begin{array}{l}\text { Log household } \\
\text { consumption } \\
\text { Monthly visits }\end{array}$} & \multicolumn{2}{|c|}{$\begin{array}{l}\text { Saw official } \\
\text { immediately }\end{array}$} & \multicolumn{3}{|c|}{ Bad service } & \multicolumn{3}{|c|}{ Good service } \\
\hline & -0.011 & -0.011 & 0.008 & 0.007 & 0.003 & 0.021 & 0.022 & 0.026 \\
\hline & $(-5.9)$ & $(-5.7)$ & $(2.9)$ & $(2.6)$ & $(1.4)$ & $(3.1)$ & $(3.3)$ & $(4.1)$ \\
\hline & 0.022 & 0.021 & -0.026 & -0.025 & -0.017 & 0.028 & 0.027 & 0.021 \\
\hline & $(8.7)$ & $(8.5)$ & $(-7.6)$ & $(-7.4)$ & $(-4.6)$ & $(2.2)$ & $(2.2)$ & $(1.7)$ \\
\hline Respondent & -0.001 & -0.001 & 0.001 & 0.001 & 0.001 & -0.003 & -0.003 & -0.003 \\
\hline education years & $(-2.2)$ & $(-2.2)$ & $(4.3)$ & $(4.4)$ & $(3.9)$ & $(-4.4)$ & $(-4.5)$ & $(-4.2)$ \\
\hline Bribe solicited by & -- & -0.10 & -- & 0.28 & 0.23 & -- & -0.22 & -0.20 \\
\hline official & & $(-12.7)$ & & $(22.9)$ & $(18.9)$ & & $(-12.4)$ & $(-10.3)$ \\
\hline Felt obliged to & -- & -0.09 & -- & 0.23 & 0.18 & -- & -0.21 & -0.19 \\
\hline bribe & & $(-9.7)$ & & $(13.2)$ & $(10.9)$ & & $(-8.2)$ & $(-6.9)$ \\
\hline Bribed voluntarily & -- & -0.05 & -- & 0.10 & 0.08 & -- & -0.08 & -0.03 \\
\hline & & $(-3.7)$ & & $(4.9)$ & $(4.2)$ & & $(-2.1)$ & $(-1.6)$ \\
\hline Refused to bribe & -- & -0.17 & -- & 0.37 & 0.25 & -- & -0.28 & -0.26 \\
\hline & & $(-13.8)$ & & $(17.2)$ & $(14.3)$ & & $(-12.0)$ & $(-10.0)$ \\
\hline $\begin{array}{l}\text { Saw official } \\
\text { immediately }\end{array}$ & -- & -- & --- & -- & $\begin{array}{l}-0.21 \\
(-39.7)\end{array}$ & -- & -- & $\begin{array}{c}0.26 \\
(18.5)\end{array}$ \\
\hline $\begin{array}{l}\text { Concluded } \\
\text { business }\end{array}$ & -- & -- & -- & -- & $\begin{array}{l}-0.14 \\
(-33.2)\end{array}$ & -- & -- & $\begin{array}{c}0.15 \\
(14.6)\end{array}$ \\
\hline Household & 0.014 & 0.013 & -0.006 & -0.004 & 0.001 & -0.009 & -0.011 & -0.015 \\
\hline extremely poor & $(4.7)$ & $(4.5)$ & $(-1.2)$ & $(-0.8)$ & $(0.3)$ & $(-0.9)$ & $(-1.1)$ & $(-1.5)$ \\
\hline Household & 0.008 & 0.007 & -0.010 & -0.009 & -0.006 & -0.010 & -0.011 & -0.015 \\
\hline moderately poor & $(4.0)$ & $(3.8)$ & $(-3.2)$ & $(-2.9)$ & $(-2.1)$ & $(-1.5)$ & $(-1.7)$ & $(-2.3)$ \\
\hline $\begin{array}{l}20 \text { official type } \\
\text { dummies }\end{array}$ & Yes & Yes & Yes & Yes & Yes & Yes & Yes & Yes \\
\hline $\begin{array}{l}\text { Respondent job } \\
\text { type }\end{array}$ & Yes & Yes & Yes & Yes & Yes & Yes & Yes & Yes \\
\hline $\begin{array}{l}\text { Remaining } \\
\text { covariates }\end{array}$ & Yes & Yes & Yes & Yes & Yes & Yes & Yes & Yes \\
\hline R-squared & 0.11 & 0.12 & 0.09 & 0.11 & 0.17 & 0.04 & 0.04 & 0.06 \\
\hline
\end{tabular}

Notes: Marginal effects from probits on 91,668 observations. T-statistics are clustered by district. The two panels of coefficients are from two different regressions. The R-squared is the same in each panel. See notes to Table 4 for a description of the covariates. 
Table 9: The financial burden of corruption by poverty status of household

\begin{tabular}{|c|c|c|c|c|}
\hline & (1) & $(2)$ & (3) & \multirow{3}{*}{$\begin{array}{c}\text { (4) } \\
\text { Share using official }\end{array}$} \\
\hline & \multicolumn{3}{|c|}{ Average bribe for users (including zeroes) } & \\
\hline & $\begin{array}{c}\text { Amount } \\
\text { (Nuevos Soles) }\end{array}$ & $\begin{array}{l}\text { As share of } \\
\text { consumption } \\
\text { (x 1000) }\end{array}$ & $\begin{array}{l}\text { As share of } \\
\text { income } \\
\text { (x 1000) }\end{array}$ & \\
\hline \multirow[t]{2}{*}{ Extremely poor } & 0.30 & 0.25 & 0.33 & \multirow[t]{2}{*}{0.09} \\
\hline & $(6)$ & $(5)$ & $(6)$ & \\
\hline \multirow[t]{2}{*}{ Moderately poor } & 0.67 & 0.25 & 0.27 & \multirow[t]{2}{*}{0.11} \\
\hline & $(18)$ & $(6)$ & $(7)$ & \\
\hline \multirow[t]{2}{*}{ Not poor } & 1.63 & 0.35 & 0.35 & \multirow[t]{2}{*}{0.14} \\
\hline & $(72)$ & $(12)$ & $(12)$ & \\
\hline \multirow[t]{2}{*}{ All } & 1.20 & 0.31 & 0.33 & \multirow[t]{2}{*}{0.12} \\
\hline & $(57)$ & $(10)$ & $(10)$ & \\
\hline Observations & & 91,668 & & 757,461 \\
\hline
\end{tabular}

Note: The unit of observation is the household-official pair. 
Table 10: The perceived burden of corruption by poverty status of the household

\begin{tabular}{|lccc|}
\hline & $(1)$ & $(2)$ & $(3)$ \\
& \multicolumn{2}{c|}{ Share of users saying significant time or money wasted } \\
& No bribery episode & Bribery episode & Difference \\
\hline Extremely poor & 0.53 & 0.85 & 0.31 \\
Moderately poor & 0.47 & 0.84 & 0.37 \\
Not poor & 0.45 & 0.82 & 0.37 \\
All & 0.46 & 0.83 & 0.36 \\
\hline Observations & 89,506 & 2123 & 91,629 \\
\hline
\end{tabular}

Note: The unit of observation is the household-official pair. The wasted time or money variable has a missing value for 39 observations in the sample. 
Appendix Table 1: Means of household characteristics

(Standard deviations in parentheses)

\begin{tabular}{|lcccc|}
\hline & $\begin{array}{c}(1) \\
\text { Full sample }\end{array}$ & $\begin{array}{c}(2) \\
\text { Used an } \\
\text { official }\end{array}$ & $\begin{array}{c}(3) \\
\text { Bribery } \\
\text { episode }\end{array}$ & $\begin{array}{c}(4) \\
\text { Reported } \\
\text { bribe amount }\end{array}$ \\
\hline Time to district administrative & 66 & 61 & 48 & 49 \\
center (minutes) & $(159)$ & $(156)$ & $(127)$ & $(137)$ \\
Town >500,000 & 0.15 & 0.16 & 0.20 & 0.19 \\
Town 100,000-500,000 & 0.22 & 0.23 & 0.26 & 0.28 \\
Town 50,000-100,000 & 0.06 & 0.06 & 0.10 & 0.10 \\
Town 20,000-50,000 & 0.08 & 0.08 & 0.09 & 0.09 \\
Town 2000-20,000 & 0.08 & 0.08 & 0.08 & 0.08 \\
Town 500-2000 & 0.05 & 0.05 & 0.03 & 0.03 \\
Town about 200 & 0.27 & 0.25 & 0.17 & 0.17 \\
Town about 100 & 0.10 & 0.09 & 0.06 & 0.06 \\
Own bike & 0.27 & 0.29 & 0.36 & 0.36 \\
Own car/van & 0.07 & 0.07 & 0.14 & 0.15 \\
Own tricycle & 0.04 & 0.05 & 0.07 & 0.07 \\
Own motorbike & 0.03 & 0.03 & 0.06 & 0.06 \\
Own truck & 0.01 & 0.01 & 0.01 & 0.01 \\
Own taxi & 0.01 & 0.01 & 0.03 & 0.03 \\
Own residence through invasion & 0.04 & 0.05 & 0.06 & 0.58 \\
Child aged 0-3 present & 0.29 & 0.30 & 0.30 & 0.31 \\
Child aged 4-7 & 0.33 & 0.36 & 0.34 & 0.36 \\
Child aged 8-11 present & 0.35 & 0.38 & 0.36 & 0.36 \\
Child aged 12-15 present & 0.33 & 0.36 & 0.34 & 0.34 \\
Household size & 4.4 & 4.6 & 4.5 & 4.6 \\
Number of earners & $(2.2)$ & $(2.2)$ & $(2.1)$ & $(2.1)$ \\
& 2.0 & 2.1 & 2.1 & 2.1 \\
Observations & $(1.1)$ & $(1.1)$ & $(1.1)$ & $(1.1)$ \\
\hline
\end{tabular}

Note: The unit of observation is the household. 
Appendix Table 2: Means of respondent characteristics

(Standard deviations in parentheses)

\begin{tabular}{|lcccc|}
\hline & $\begin{array}{c}(1) \\
\text { Full sample }\end{array}$ & $\begin{array}{c}(2) \\
\text { Used an } \\
\text { official }\end{array}$ & $\begin{array}{c}(3) \\
\text { Bribery } \\
\text { episode }\end{array}$ & $\begin{array}{c}\text { Reported bribe } \\
\text { amount }\end{array}$ \\
\hline Male & 0.48 & 0.47 & 0.55 & 0.50 \\
Age & 41.1 & 40.1 & 37.5 & 37.3 \\
Years education & $(16.5)$ & $(15.6)$ & $(13.3)$ & $(13.4)$ \\
& 7.7 & 8.1 & 9.8 & 9.9 \\
Married or cohabiting & $(4.8)$ & $(4.8)$ & $(4.5)$ & $(4.5)$ \\
Married/cohabiting*male & 0.64 & 0.66 & 0.65 & 0.67 \\
Not employed & 0.32 & 0.33 & 0.37 & 0.38 \\
Non-agricultural employer & 0.22 & 0.22 & 0.19 & 0.20 \\
Agricultural employer & 0.02 & 0.02 & 0.04 & 0.05 \\
Non-agricultural self-employed & 0.03 & 0.03 & 0.03 & 0.03 \\
Agricultural self-employed & 0.19 & 0.19 & 0.25 & 0.26 \\
White collar & 0.16 & 0.15 & 0.09 & 0.08 \\
Blue collar & 0.12 & 0.13 & 0.18 & 0.18 \\
Unpaid family worker & 0.12 & 0.11 & 0.11 & 0.11 \\
Domestic worker & 0.13 & 0.13 & 0.09 & 0.08 \\
Other worker & 0.01 & 0.01 & 0.01 & 0.01 \\
Employer with >10 workers & 0.004 & 0.003 & 0.003 & 0.001 \\
In school & 0.003 & 0.003 & 0.004 & 0.004 \\
In military/police & 0.06 & 0.06 & 0.08 & 0.08 \\
In public administration & 0.005 & 0.005 & 0.006 & 0.006 \\
\hline Observations & 0.06 & 0.07 & 0.09 & 0.09 \\
\hline & 36,080 & 30,889 & 1,774 & 1,415 \\
\hline
\end{tabular}

Note: The unit of observation is the household. 